Special Issue (October)

\title{
EFFECT OF PROPOLIS EXTRACT AND PROPOLIS CANDIES ON STREPTOCOCCUS SOBRINUS GROWTH
}

\section{HANNY FAIZAH, RATNA FARIDA*, NURTAMI SOEDARSONO}

Department of Oral Biology, Faculty of Dentistry, Universitas Indonesia, Jakarta, Indonesia. Email: friedakuayu@yahoo.co.id

Received: 20 April 2017, Revised and Accepted: 13 July 2017

ABSTRACT

Objectives: The objective of this study analyzes the effect of propolis extract and propolis candies on Streptococcus sobrinus growth.

Methods: S. sobrinus was exposed to propolis extract and propolis candies. The minimum inhibitory concentration (MIC) and minimum bactericidal concentration (MBC) were determined through spectrophotometric analysis and the S. sobrinus colonies were counted using the standard plate counted method.

Result: MIC was 5\% and MBC was 10\%. S. sobrinus colonies decreased after exposure to propolis extract and propolis candies.

Conclusions: Propolis extract and propolis candies could inhibit the growth of S. sobrinus.

Keywords: Propolis, Flavonoid, Streptococcus sobrinus, Caries.

(C) 2017 The Authors. Published by Innovare Academic Sciences PvtLtd. This is an open accessarticle under the CC BY license (http://creativecommons. org/licenses/by/4. 0/) DOI: http://dx.doi.org/10.22159/ajpcr.2017.v10s5.23085

\section{INTRODUCTION}

Conventionally, herbal medicines have been used in Indonesia because their ingredients are relatively safe compared to synthetic drugs [1]. Indonesia has abundant natural resources that are easy to obtain-more than 9609 species of plants that can be sourced for herbal medicines [2]. One ingredient found in Indonesia that may inhibit bacteria colonization is propolis [3]. Flavonoid is believed to be a component of propolis [4]. The antibacterial properties of flavonoids have been proven by the previous studies; for example, the studies found that propolis might decrease Staphylococcus aureus and Streptococcus mutans bacteria inside the oral cavity [4,5]. Honey is another herbal ingredient with antibacterial properties. Its wound healing, infection-fighting, and inflammation-reducing abilities have been tested experimentally and clinically in the medical field. Like propolis, honey contains a bioactive ingredient (similar to flavonoid) that is responsible for its antibacterial effect.

In general, oral disease can be divided into two categories: Soft and hard tissue. The most common hard tissue disease is dental caries. The etiology of dental caries is highly influenced by plaque. Dental plaque is an oral biofilm that grows on the surface of teeth. Although the flora of the oral cavity is varied and complex, two species of streptococcus are most commonly associated with dental caries: $S$. mutans and Streptococcus sobrinus [6]. Propolis has been developed into an oral health product that comes in capsule, liquid, toothpaste, and mouthwash forms. In this study, propolis was packed into candies to make consumption more practical. Previous studies proved that honey propolis candies decrease the prevalence of $S$. mutans in the oral cavity. Therefore, the prohibitive effect of propolis extract and propolis candies on $S$. sobrinus growth was tested in this study.

\section{METHODS}

Making the $S$. sobrinus bacteria solution

A colony of $S$. sobrinus bacteria was transferred from a Petri dish into a brain heart infusion (BHI) medium. The centrifuge tube containing the BHI and S. sobrinus culture was incubated for $1 \times 24$ hrs in an anaerobic environment.
Making the propolis extract solutions

Concentrations of $0.5 \%, 1 \%, 5 \%, 10 \%$, and $20 \%$ propolis solution were used in this study. A $20 \%$ glycerin solution was used to dilute the propolis extract to obtain the desirable concentrations. The propolis extracts were filtrated using a $0.22 \mu \mathrm{L}$ syringe filter. The extract solutions were stored inside a $4^{\circ} \mathrm{C}$ refrigerator until their use.

\section{Making the candy solution}

First, propolis honey sucrose candies, propolis honey palm sugar candies, and $\mathrm{X}$ propolis candies were weighed. Then, the candies were mashed into small pieces using a mortar and pestle. The three types of candies were crushed up individually, into 3 separate mixtures. The candy powder was then transferred into an Erlenmeyer that contained $10 \mathrm{~mL}$ of BHI solution. Next, the candy solution was filtrated using a $0.22 \mu \mathrm{L}$ syringe filter and stored inside a $4^{\circ} \mathrm{C}$ refrigerator until its use.

Determining the minimum inhibitory concentration (MIC) and minimum bactericidal concentration (MBC)

The $S$. sobrinus bacteria suspension was transferred into 96-well plates in triplo; either $100 \mu \mathrm{L}$ of propolis extract solution or no propolis extract (the control) was then added into the 96-well plate. The samples were incubated for $1 \times 24 \mathrm{hrs}$ in an anaerobic environment. Afterward, the optical density reading was taken using an ELISA reader with a $450 \mathrm{~nm}$ wave length. The formula for the MIC is shown below:

Inhibition $\%=1-\left(\frac{\text { OD sample-OD blank }}{\text { OD control-OD BHI }}\right)$

The MIC was determined based on the inhibition number reaching $\geq 90 \%$. The sample result was placed in $10 \mu \mathrm{L}$ of $\mathrm{BHI}$ agar. The lowest concentration of propolis extract with zero bacterial growth on the BHI agar was designated the MBC.

\section{Quantitative bacteria test after candy exposure}

The $S$. sobrinus suspension was transferred into a 96-well plate in $100 \mu \mathrm{L}$ increments. Each bacteria-containing well was exposed to one of the four: $100 \mu \mathrm{L}$ of the propolis honey sucrose sweetener candy 
Table 1: Inhibition values of propolis extracts against Streptococcus sobrinus bacteria

\begin{tabular}{|c|c|c|c|c|c|}
\hline \multirow{2}{*}{$\begin{array}{l}\text { Propolis extract and control } \\
\text { group concentration }(\%)\end{array}$} & \multicolumn{3}{|c|}{ Inhibition value $(\%)$} & \multirow{2}{*}{$\begin{array}{l}\text { Inhibition mean } \\
\text { value }(\%) \pm S D\end{array}$} & \multirow{2}{*}{$\begin{array}{l}\text { p-value against control } \\
\text { group (no propolis extract) }\end{array}$} \\
\hline & Sample I & Sample II & Sample III & & \\
\hline Control group (no propolis extract) & 0 & 0 & 0 & 0 & $0.000^{*}$ \\
\hline 1 & 71 & 71 & 72 & $72 \pm 0.57$ & $0.000^{*}$ \\
\hline 5 & 93.5 & 93.8 & 94.3 & $93.9 \pm 0.39$ & $0.000^{*}$ \\
\hline 10 & 93.9 & 94.2 & 94.4 & $94.2 \pm 0.25$ & $0.000^{*}$ \\
\hline 15 & 47 & 42 & 43 & $44 \pm 0.26$ & $0.000^{*}$ \\
\hline 20 & 33 & 34 & 32 & $33 \pm 1$ & $0.000^{*}$ \\
\hline
\end{tabular}

*There were significant differences $(\mathrm{p}<0.025)$, SD: Standard deviation

Table 2: $S$. sobrinus colony calculations after propolis extract exposure

\begin{tabular}{ll}
\hline $\begin{array}{l}\text { Propolis extract and control } \\
\text { group concentration }\end{array}$ & $\begin{array}{l}\text { Number of Streptococcus } \\
\left.\text { sobrinus colonies } \mathbf{( 1 0 ^ { 5 }} \mathbf{C F U} / \mathbf{m L}\right)\end{array}$ \\
\hline $\begin{array}{l}\text { Control group (no propolis } \\
\text { extract) (\%) }\end{array}$ & 780 \\
0.5 & 48 \\
1 & 23 \\
5 & 9 \\
10 & 0 \\
15 & 0 \\
20 & 0 \\
\hline S. sobrinus: Streptococcus sobrinus &
\end{tabular}

S. sobrinus: Streptococcus sobrinus

solution, propolis honey palm sugar candy solution, $\mathrm{X}$ propolis candy solution, and control (without propolis solution). The samples were incubated for $1 \times 24 \mathrm{hrs}$ in an anaerobic environment. Next, $10 \mu \mathrm{L}$ of each microplate sample was transferred by Eppendorf pipette to solid agar and smeared using a wire loop. The samples were then incubated for $1 \times 24 \mathrm{hrs}$ at $37^{\circ} \mathrm{C}$. The colony-forming units (CFU) on the surface of the BHI agar were calculated using the standard plate count (SPC) method.

\section{RESULTS}

The results of the propolis extract's inhibition of S. sobrinus are shown in Table 1.

The inhibition mean value of the $0.5 \%$ propolis extract was $58 \%( \pm 2.51)$ and the p-value, obtained through comparison to the control group, was $<0.025$. MIC is determined from inhibition values of $\geq 90 \%$. As shown in Table 1, the first propolis extract solution to reach $90 \%$ was the $5 \%$ concentration. Table 2 shows calculations of the $S$. sobrinus colonies exposed to propolis extract.

As shown in Table 2 , the $0.5 \%$ propolis extract $S$. sobrinus colony concentration was $48 \times 10^{5} \mathrm{CFU} / \mathrm{ml}$. In the $1 \%$ and $5 \%$ propolis extracts, the $S$. sobrinus colony concentrations were $23 \times 10^{5} \mathrm{CFU} / \mathrm{mL}$ and $9 \times 10^{5} \mathrm{CFU} / \mathrm{mL}$, respectively. No bacteria colonies grew in the BHI agar for the $10 \%, 15 \%$, or $20 \%$ propolis extract concentrations. The lowest propolis extract concentration that had no S. sobrinus colony, the $10 \%$ concentration, was designated the MBC. Therefore, the MBC score of the propolis extract was $10 \%$. Table 3 shows the bacterial colony counts after exposure to honey propolis palm sugar candies, honey propolis sucrose sweetener candies, and X propolis sugar candies.

As shown in Table 3, the lowest bacterial colony count occurred after exposure to propolis palm sugar candies $\left(131 \times 10^{5} \mathrm{CFU} / \mathrm{ml}\right)$. The ANOVA showed a significant difference $(p<0.025)$ between the propolis palm sugar candy group and the control group. S. sobrinus colonies also decreased in the honey propolis sucrose sweetener candy $\left(208 \times 10^{5} \mathrm{CFU} / \mathrm{ml}\right)$ and $\mathrm{X}$ propolis candy $\left(345.5 \times 10^{5} \mathrm{CFU} / \mathrm{ml}\right)$ groups. However, a one-way ANOVA test between these groups showed no significant difference ( $p>0.025)$.

\section{DISCUSSION}

Based on the results, it appears that the flavonoid properties in propolis inhibit the growth of $S$. sobrinus. Flavonoid destroys the cytoplasmic membrane, causing leakage of the cell contents [1]. Propolis most effectively inhibits the growth of $S$. sobrinus during cell division. During this process, the thin surface layer allows the flavonoid to easily penetrate the cell wall and damage the cell's contents [7]. Propolis' phenol properties may also inhibit the growth of $S$. sobrinus. These compounds bind to bacterial proteins. A weak bond between the protein-phenol forms in low concentrations, allowing phenol penetration into the cells, which denatures the protein and inhibits bacterial growth. In high concentrations, phenol can cause protein coagulation and lysis of the cell membrane. Barrientos et al. (2013) stated that the active substance in propolis depends on the compound's species and collection location [8]. Propolis extracts with higher levels of active substances can more effectively inhibit bacteria growth [8]. The local propolis used in this study had $0.26 \%$ flavonoid, whereas Turkish propolis has a flavonoid content of $13.5 \%$.

This study's test results showed that the $0.5-10 \%$ propolis concentrations had increasing values of inhibition. However, the propolis extract's inhibition against the S. sobrinus declined at $15 \%$ and $20 \%$ concentrations. These results differed from the BHI agar colony counts, where the higher concentrations of propolis extract resulted in the growth of fewer colonies. The inhibition value in this study was obtained from the optical density sample. Several factors determine the reading of optical density, such as consistency and specimen color [8]. In this study, the 15\% and $20 \%$ concentration solutions of propolis extract had more consistency and concentrated color than the $0.5 \%, 1 \%$, and $10 \%$ concentrations. This led to increased optical density for the $15 \%$ and $20 \%$ concentrations. Optical density values reflect the accumulation of live and dead bacteria [9]. Hence, it is possible that the solutions with the highest optical density had no existing live bacteria. Sekse et al. stated that when assessing the growth of bacteria, the optical density reading is not always identical to the calculation results of bacteria on agar [10]. Therefore, a SPC method was used in this study to control the optical density value.

This study results showed that honey propolis palm sugar candies, honey propolis sucrose sweetener candies, and X propolis candies all decreased the colonization of $S$. sobrinus bacteria compared to the control group. The bacterial colonies for the honey propolis palm sugar candy test group decreased more significantly than the colonies for the honey propolis sucrose sweetener candy and X propolis candy groups. It can be concluded that honey propolis palm sugar candy more effectively inhibits the growth of $S$. sobrinus than honey propolis sucrose sweetener candy and X propolis sugar candy. This could be due to the difference in sucrose content between the honey propolis palm sugar candy and propolis honey sucrose sweetener candy. Carbohydrate intake contributes to the growth of $S$. sobrinus. Previous study stated that streptococci bacteria grow quickly because they can utilize various types of carbohydrates as additional nutrients for metabolism and cell growth [11]. This occurs because $S$. sobrinus can produce enzymes that catalyze hydrolysis. Sucrose is a carbohydrate utilized by S. sobrinus in the process of fermentation. Fewer $S$. sobrinus colonies were present 
Table 3: Mean bacterial colony count after exposed with propolis candies

\begin{tabular}{|c|c|c|c|c|}
\hline Propolis candy and control group & \multicolumn{2}{|c|}{$\begin{array}{l}\text { Colony count } \\
\text { Streptococcus } \\
\text { sobrinus }\left(10^{5} \mathrm{CFU} / \mathrm{mL}\right)\end{array}$} & $\begin{array}{l}\text { Mean Streptococcus sobrinus } \\
\text { colony count } \pm \text { SD }\left(10^{5} \mathrm{CFU} / \mathrm{mL}\right)\end{array}$ & $\begin{array}{l}\text { p-value against control } \\
\text { group (without propolis) }\end{array}$ \\
\hline Control group (no propolis) & 780 & 1550 & $1115 \pm 403$ & \\
\hline PA & 113 & 149 & $131 \pm 25.45$ & $0.019 *$ \\
\hline PM & 201 & 215 & $208 \pm 9.89$ & 0.027 \\
\hline
\end{tabular}

*There were significant differences $(\mathrm{p}<0.025)$. PA: Honey propolis palm sugar candies, PM: Honey propolis sucrose sweetener candies, PX: $\mathrm{X}$ propolis candies,

S. sobrinus: Streptococcus sobrinus

after exposure to honey propolis palm sugar candy versus propolis honey sucrose sweetener candy.

The propolis candies contained $5 \%$ propolis extract $9 \times 10^{5} \mathrm{CFU} / \mathrm{mL}$ of colonized S. sobrinus was observed after exposure to the $5 \%$ propolis extract, whereas the mean $S$. sobrinus population after consecutive exposures to honey propolis palm sugar and honey propolis sucrose sweetener candies was $131 \times 10^{5} \mathrm{CFU} / \mathrm{mL}$ and $208 \times 10^{5} \mathrm{CFU} / \mathrm{mL}$, respectively. This result shows that propolis extract more effectively prohibits the growth of S. sobrinus bacteria than honey propolis candy. The sugar content of the honey propolis candy likely lessened its prohibitive effect.

\section{CONCLUSIONS}

This study concludes that propolis extract may inhibit the growth of S. sobrinus with a $5 \%$ MIC value and $10 \%$ MBC. Propolis honey sugar palm candy more effectively prohibited $S$. sobrinus bacteria colonization than propolis honey sucrose sweetener candy and X propolis candy. More research is needed regarding the components contained in the propolis honey candy, particularly palm sugar and sugar and how each affects bacterial growth.

\section{REFERENCES}

1. Widjidjono H. Penggunaan herbal di bidang kedokteran gigi. Majalah Kedokt Gig 2008;15(1):61-4.
2. Wasito $\mathrm{H}$. The role of pharmacy college in the development of small industry of traditional medicine for poverty alleviation. Maj Ilm Kop WIIV 2008;8.

3. Bogdanov S. Propolis: Composition, Health, Medicine: A review. Bee Prod Sci 2014;1(6):63.

4. Parolia AS, Thomas M, Kundabala M. Propolis and its potential uses in oral health. Int J Med Sci 2010;2(7):201-5.

5. Gladea Z. Pengaruh Pengkonsumsian Permen Propolis Madu Terhadap Prevalensi Streptococcus mutans Pada Penderita Karies. Indonesia: UI Press: Universitas; 2012.

6. Duggal P. Honey bee: The healer!!! propolis (propolis cera). Guident 2013;6(4):72-6

7. Loesche WJ. Role of Streptococcus mutans in human dental decay. Microbiol Rev 1986;50(4):353-80.

8. Barrientos L, Herrera CL, Montenegro G, Ortega X, Veloz J, Alvear M, et al. Chemical and botanical characterization of Chilean propolis and biological activity on cariogenic bacteria Streptococcus mutans and Streptococcus sobrinus. Braz J Microbiol 2013;44(2):577-85.

9. Sutton S. Measurement of microbial cells by optical density. J Validation Technol 2011;17(1):46-9.

10. Sekse C, Bohlin J, Skjerve E, Vegarud GE. Growth comparison of several Escherichia coli strains exposed to various concentrations of lactoferrin using linear spline regression. Microb Inform Exp 2012;2:5.

11. Kakuta H, Iwami Y, Mayanagi H, Takahashi N. Xylitol inhibition of acid production and growth of mutans streptococci in the presence of various dietary sugars under strictly anaerobic conditions. Caries Res 2003;37(6):404-9. 